\title{
Arsenic Release from Contaminated Soil of Bangladesh in Natural Field Conditions
}

\author{
M. S. Azam ${ }^{1 *}$, M. Shafiquzzaman ${ }^{1}$, Iori Mishima ${ }^{2}$, and Jun Nakajima ${ }^{1}$ \\ ${ }^{1}$ Department of Environmental Systems Engineeering, Ritsumeikan University, Nojihigashi 1-1-1, \\ Kusatsu, Shiga, 525-8577, Japan \\ ${ }^{2}$ Center for Environmental Science, Saitama, Japan
}

Received 16 December 2008, accepted in final revised form 25 February 2009

\begin{abstract}
Leaching experiment was conducted to understand the mechanism of arsenic release from soil in the natural field conditions. Two types of column were run, one with de-ionized water (DW) and another with synthetic Bangladesh groundwater $(\mathrm{GW})$ as influent which simulated rainfall and groundwater conditions, respectively. As the primary mechanism for the arsenic release from soil it was identified that the redox potential (Eh) was major importance. In highly reducing conditions both arsenic and iron release was high. Released mass of arsenic was higher in DW column than GW column. The difference was caused by the presence of calcium and magnesium ion in the synthetic groundwater. Comparing to the acid-alkali sequential extraction it was found that calcium and magnesium prohibited the release of arsenic bound with iron. The effect of calcium and magnesium was clarified in the batch experiment performed in the study.
\end{abstract}

Keywords: Paddy field; Groundwater; Arsenic; Redox potential; pH.

(C) 2009 JSR Publications. ISSN: 2070-0237 (Print); 2070-0245 (Online). All rights reserved.

DOI: $10.3329 /$ jsr.vli2.1708

\section{Introduction}

Arsenic (As) in groundwater is a major health concern in Asia and the risks created from using shallow tube wells for drinking-water are well-known. Anthropogenic sources of As include various industrial activities, pesticides, herbicides, and fertilizers [1]. At present, several countries have reported high As levels in part of their groundwater resources such as Bangladesh, Cambodia, China, India, Lao PDR, Nepal, Pakistan, Thailand, Viet Nam and more cases are being reported and published [2-6]. As part of the green revolution, thousands of shallow tube wells have been installed throughout Bangladesh. This has resulted in a sharp increase of groundwater extraction for irrigation. It has been estimated that water extraction from the shallow aquifer for irrigation adds 1 million $\mathrm{kg}$ of As per year to the arable soil, mainly in the paddy fields which alarms for the dietary intake of As

\footnotetext{
*Corresponding author: shiponb@yahoo.com
} 
through food chain [7].

As has four main chemical forms having oxidation states, $-3,0,+3$, and +5 , but in natural water its predominant forms are inorganic oxyanions of trivalent arsenite [As (III)] or pentavalent arsenate [As (V)] [8]. As (III) has a higher solubility than As (V), resulting in a higher mobility of As in flooded soils. The transport of As from soil to groundwater or vice versa is dependent on soil-water interaction in the subsurface environment. Oxidation/reduction state in soil layer is a controlling chemical factor for As transportation. Redox conditions in soil layers vary widely from $+500 \mathrm{mV}$ (surface soils) to $-300 \mathrm{mV}$ (strongly reducing conditions) [9]. Iron ( $\mathrm{Fe}$ ) oxides, clay minerals, and organic materials in soil will adsorb or desorb As when the ionic composition and/or Eh-pH in soil water changes [10]. Flooding or transport of organic material or other reducing agents into soil can initiate reduction condition and subsequently lead to dissolution of ferric hydroxides [11]. One important mechanism through which the groundwater is polluted with As is the reductive dissolution of iron oxyhydroxide $(\mathrm{FeOOH})$ stimulated by microbial activity and organic materials [8, 12-16].

Leaching tests are important tools commonly used to determine the leachability and mobility of inorganic contaminants. Column leaching tests were conducted to study As mobility through sand bed and were reported in previous studies [17, 18]. Column experiments with controlled $\mathrm{pH}$ and redox potential (Eh) to address the effect of $\mathrm{pH}$ and $\mathrm{Eh}$ on As mobility are also conducted in several studies [19, 20]. However, in natural field conditions rainwater infiltration and paddy field inundated by groundwater during irrigation has the potential effects for the As movement or release from the soil. Therefore, the main objective of this study is to simulate rainfall and groundwater conditions to understand the As movement/release under natural field conditions. Accordingly, column as well as batch leaching experiment has been conducted with original As contaminated soil collected from paddy field of Bangladesh.

\section{Materials and Methods}

\subsection{Soil sample collection and preparation}

As contaminated soil sample was collected in August, 2007 from a paddy field in Mollahat subdistrict of Bagerhat district situated in south western region of Bangladesh. High As contaminated groundwater $(250 \sim 300 \mu \mathrm{g} / \mathrm{L})$ was used about 4 months per year for irrigation. A representative top surface (depth: $0 \sim 10 \mathrm{~cm}$ ) was collected. Prior to characterization and leaching experiments, the soil was air-dried and sieved at $0.5 \mathrm{~mm}$ to remove coarse debris and gravel, homogenized, and stored in the laboratory.

\subsection{Synthetic groundwater}

The synthetic Bangladesh groundwater $(\mathrm{GW})$ without Fe and As was prepared by dissolution of specific chemicals in de-ionized water. In order to clarify the relationship 
between As solubility and Fe content of the soil sample Fe was not used. Arsenic was not added in the GW to avoid adsorption and to understand only the As release mechanism from the contaminated soil. The chemical composition of this synthetic groundwater similar to main characteristics of Bangladesh groundwater was shown in Table 1 (BGS). Each liter of synthetic water consisted, commonly, of $\mathrm{NH}_{4} \mathrm{Cl} 10 \mathrm{mg}, \mathrm{MgSO}_{4} .7 \mathrm{H}_{2} \mathrm{O} 500 \mathrm{mg}, \mathrm{NaCl} 1.2 \mathrm{mg}$, $\mathrm{KH}_{2} \mathrm{PO}_{4} 5 \mathrm{mg}, \mathrm{CaCl}_{2} .2 \mathrm{H}_{2} \mathrm{O} 400 \mathrm{mg}, \mathrm{MnSO}_{4} .5 \mathrm{H}_{2} \mathrm{O} 2 \mathrm{mg}$ and $\mathrm{NaHCO}_{3} 50 \mathrm{mg}$.

Table 1. Characteristics of synthetic groundwater used in this study and Bangladesh groundwater obtained from BGS (British Geological Survey) Data Base (2000) [21].

\begin{tabular}{ccc}
\hline & Bangladesh groundwater & Synthetic groundwater \\
\hline $\mathrm{pH}$ & 7.2 & $6.8-7.2$ \\
$\mathrm{Ca}$ & $40-100 \mathrm{mg} / \mathrm{l}$ & $100 \mathrm{mg} / \mathrm{l}$ \\
$\mathrm{Mg}$ & $20-70 \mathrm{mg} / \mathrm{l}$ & $40 \mathrm{mg} / \mathrm{l}$ \\
$\mathrm{P}$ & $1.6-2.7 \mathrm{mg} / \mathrm{l}$ & $1.0 \mathrm{mg} / \mathrm{l}$ \\
$\mathrm{Mn}$ & $0.2-0.4 \mathrm{mg} / \mathrm{l}$ & $0.45 \mathrm{mg} / \mathrm{l}$ \\
$\mathrm{Fe}$ & $3-20 \mathrm{mg} / \mathrm{l}$ & - \\
$\mathrm{As}$ & $250-1000 \mu \mathrm{g} / \mathrm{l}$ & - \\
\hline
\end{tabular}

\subsection{Continuous column leaching experiment}

Continuous column leaching experiment are more accurate than batch leaching experiments for representing the real environmental conditions [22]. In order to evaluate the impacts of actual field conditions on the leaching ability of As, continuous column leaching experiments were conducted under two conditions at room temperature. DW was used to simulate the rainwater condition and GW was used to simulate irrigation groundwater as influent in the column study. The tests under each condition were conducted in duplicate (DW A, B; GW A, B). Four acryl columns of $7.9 \mathrm{~cm}$ inside diameter and $16 \mathrm{~cm}$ length were filled with the dried soil sample up to $13 \mathrm{~cm}$. A schematic diagram is represented in Fig.1.

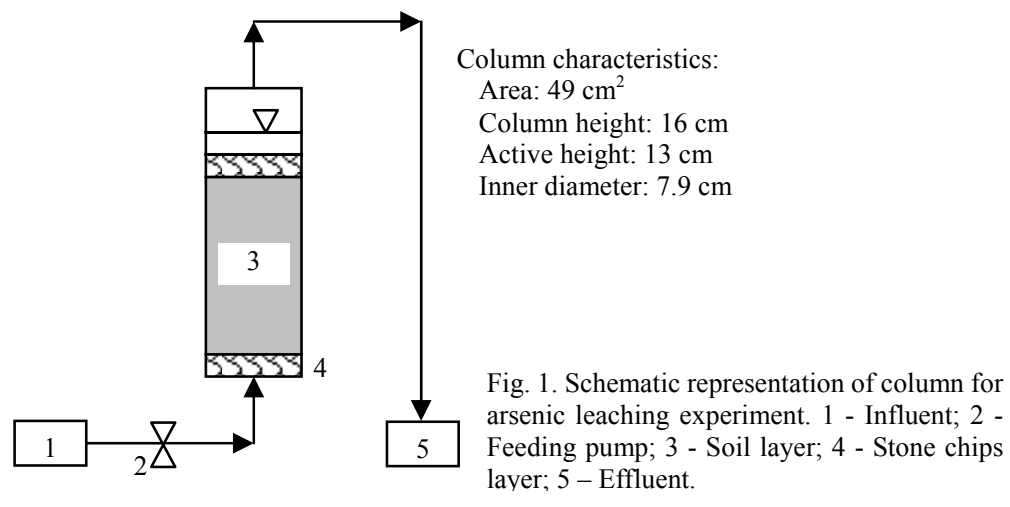

Columns were run at a flow rate of $0.10 \mathrm{ml} / \mathrm{min}$ (linear velocity $2.94 \mathrm{~cm} /$ day) for a period of 
174 days. The columns were sampled twice in a week. In order to provide oxygen free environment, influent water was purged with nitrogen gas for at least 30 mins prior to use. $\mathrm{pH}$ and DO of effluent samples collected were measured immediately and Eh was measured at the top of the column at the same time. Samples were kept in the refrigerator at $4^{0} \mathrm{C}$ until analysis. Effluent samples were then analyzed for the total $\mathrm{As}, \mathrm{Fe}, \mathrm{Ca}, \mathrm{Mg}$ and $\mathrm{Mn}$ concentrations.

\subsection{Batch leaching experiment}

Five desorption batch leaching studies were conducted to evaluate the leaching ability of As under different conditions of $\mathrm{Ca}$ and $\mathrm{Mg}$. Batch experiments were initiated by mixing $1.0 \mathrm{~g}$ of soil sample with $100 \mathrm{ml}$ extractant solutions (Table 2) into different Teflon bottles. Then the mixed liquor was shaken at $140 \mathrm{rpm}$ for $24 \mathrm{hrs}$. In order to provide oxygen free environment, extractant was purged with nitrogen gas for at least 30 min prior to use. $\mathrm{pH}$ and Eh of the mixed liquor were measured after shaking. Then the mixed liquor was filtered through $1.0 \mu \mathrm{m}$ Advantec No. 5C filter paper and then As, Fe, Mn, Ca and Mg of the filtrate were measured.

Table 2. Details of batch experiment.

\begin{tabular}{cccc}
\hline Batch No & Extractant solution & Initial pH & Initial Eh $(\mathrm{mV})$ \\
\hline B-1 & DW & 5.9 & 130 \\
B-2 & GW & 8.1 & 160 \\
B-3 & GW (- Ca and - Mg) & 7.9 & 140 \\
B-4 & GW (- Ca and + Mg) & 7.8 & 145 \\
B-5 & GW (+ Ca and - Mg) & 7.9 & 150 \\
\hline
\end{tabular}

\subsection{Sequential extraction procedure}

Extraction step consists of taking $1.0 \mathrm{~g}$ of oven-dried soil into a Teflon bottle and mixed with $50 \mathrm{ml}$ of $0.1 \mathrm{~N} \mathrm{HCl}$ and shaken for 3 minutes at room temperature. The acid extract was obtained by filtration through $1.0 \mu \mathrm{m}$ Advantec No. $5 \mathrm{C}$ filter paper. The remaining residue was then put into the same bottle mixed with $100 \mathrm{ml}$ of $0.1 \mathrm{~N} \mathrm{NaOH}$ and was shaken for 17 hrs. The mixture was centrifuged and the supernatant was decanted and filtered through 1.0 $\mu \mathrm{m}$ Advantec No. 5C filter paper. The first fraction provides easily soluble As and second fraction As bound to Fe oxides [23].

\subsection{Analytical method}

Arsenic standard stock solution of internal standard (1000 ppm), $\mathrm{HCl}(35 \%), \mathrm{HNO}_{3}(60 \%)$, $\mathrm{NH}_{4} \mathrm{Cl}(99.0 \%), \mathrm{KH}_{2} \mathrm{PO}_{4}(99.0 \%)$ and $\mathrm{NaOH}(96 \%)$ were purchased from Nacalai tesque. Inc. Kyoto, Japan. Iron (Fe), Phosphorus (P), Calcium (Ca), Magnesium ( $\mathrm{Mg}$ ) and Manganese (Mn) stock solution (1000 ppm), $\mathrm{NaHCO}_{3}(99.5 \%), \mathrm{MgSO}_{4} .7 \mathrm{H}_{2} \mathrm{O}(99.5 \%)$, $\mathrm{NaCl}(99.5 \%), \mathrm{CaCl}_{2} .2 \mathrm{H}_{2} \mathrm{O}(99.0 \sim 103.0 \%), \mathrm{MnSO}_{4} .5 \mathrm{H}_{2} \mathrm{O}(99.0 \%)$ were obtained from Wako Pure Chemical Industries Ltd. Japan. Fresh calibration standards were prepared by 
diluting analytical standards in 5\% nitric acid. Particle size distribution was measured by the laser diffraction method (Shimadzu SALD 3000). Bulk density of soil was measured using the core and density bottle method. Soil $\mathrm{pH}$ was determined with 1:2 soil/water suspension using $\mathrm{pH}$ meter (Horiba, Japan). Oxidation reduction potential (ORP) was measured by UC-23 Digital pH/ORP meter (CKC) and converted to Eh. Organic matter $(\mathrm{OM})$ was determined by the percentage of weight loss after ignition $\left(600^{\circ} \mathrm{C}\right.$ for $\left.1 \mathrm{hr}\right)$. Total concentration of $\mathrm{As}, \mathrm{P}, \mathrm{Fe}, \mathrm{Ca}, \mathrm{Mg}$ and $\mathrm{Mn}$ were measured after hot acid digestion with aqua regia $\left(\mathrm{HCl}\right.$ and $\mathrm{HNO}_{3}$ ). As was analyzed by using polarized Zeeman GFAAS equipped with graphite tube atomizer and programmable auto sampler (Hitachi Z2700). P was determined by Molybdenum blue colorimetric method (JIS K 0102). Fe, Mn, Ca and $\mathrm{Mg}$ were determined by inductively coupled plasma atomic emission spectrometry (ICP-AES) (Seiko SPS 4000).

\section{Results}

\subsection{Soil sample characterization}

Table 3 lists the physical and chemical characteristics of the soil sample. Soil $\mathrm{pH}$ was slightly acidic and particle size distribution indicated a soil texture as silty sand. The soil was observed to have high concentration of As $(97.2 \mu \mathrm{g} / \mathrm{g})$. This seemed to be caused by high As contaminated irrigation groundwater $(250 \sim 300 \mu \mathrm{g} / \mathrm{L})$. In Bangladesh, As levels in soil is generally less than $10 \mu \mathrm{g} / \mathrm{g}$, whereas the concentration is greater than $40 \mu \mathrm{g} / \mathrm{g}$ in the soil that receives irrigation with the As contaminated water [24]. The results of the acid-alkali sequential extraction indicated that most of As (66\%) was in Fe bound fraction $(0.1 \mathrm{~N} \mathrm{NaOH}$ extracted $)$ and $23 \%$ of the total As was easily soluble fraction $(0.1 \mathrm{~N} \mathrm{HCl}$ extracted).

Table 3. Physical and chemical characteristics of soil.

\begin{tabular}{lrlr}
\hline Physical Characteristics & \multicolumn{3}{l}{ Chemical Characteristics } \\
\hline Soil pH in water & 6.4 & Soil As content $(\mu \mathrm{g} / \mathrm{g})$ & 97.2 \\
Bulk density $\left(\mathrm{g} / \mathrm{cm}^{3}\right)$ & 1.55 & $\mathrm{Fe}(\mathrm{mg} / \mathrm{g})$ & 45.5 \\
Organic matter content $(\%)$ & 7.6 & $\mathrm{Ca}(\mathrm{mg} / \mathrm{g})$ & 8.04 \\
Sand $(\%)$ & 44.3 & $\mathrm{Mg}(\mathrm{mg} / \mathrm{g})$ & 11.9 \\
Silt $(\%)$ & 47.8 & $\mathrm{Mn}(\mathrm{mg} / \mathrm{g})$ & 0.43 \\
Clay $(\%)$ & 7.90 & $\mathrm{P}(\mathrm{mg} / \mathrm{g})$ & 0.86 \\
\hline
\end{tabular}

\subsection{Column leaching experiments}

\subsubsection{GW column}

Fig. 2 shows the changes of $\mathrm{pH}$ and Eh of the GW column effluents with time. The $\mathrm{pH}$ of effluent was changed between 6.8 and 8.2 and was higher in first 60 days compared to the 

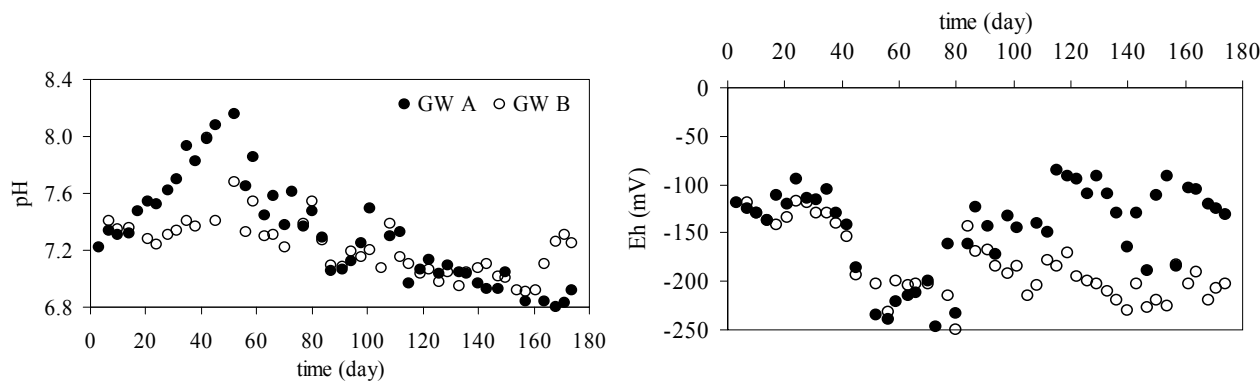

Fig. 2. Changes of $\mathrm{pH}$ and Eh values of effluents from GW soil columns with time.
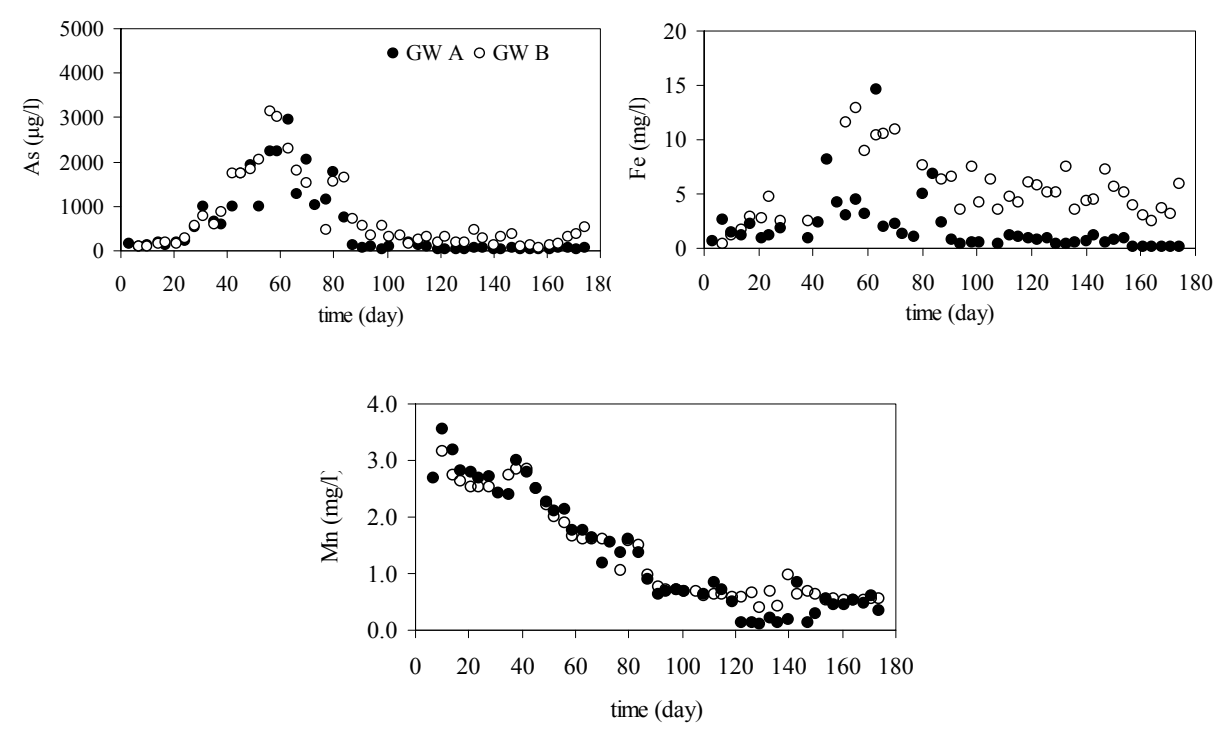

Fig. 3. Changes of effluent As, Fe and Mn of GW columns with time.

rest of the time. Eh of effluents remained less than $-100 \mathrm{mV}$ almost during the whole experiment period indicating a high reducing condition.

Fig. 3 shows the changes of As, Fe and Mn concentrations of the GW column effluents with time. Effluent As concentration was increased until 60 days and maximum concentration was $2950 \mu \mathrm{g} / \mathrm{L}$ and $3150 \mu \mathrm{g} / \mathrm{L}$ of the GW A and GW B column, respectively. After 90 days As concentration decreased and became less than $500 \mu \mathrm{g} / \mathrm{L}$ in both columns. Fe concentration fluctuated in a wide range but higher in GW B column compared to GW A after 60 days. Eh of GW B column in this period was almost $-200 \mathrm{mV}$ that seemed to be the cause for higher effluent Fe concentration compared to GW A. Mn concentration was higher initially which was more than $3.0 \mathrm{mg} / \mathrm{L}$ and decreased with time.

The mass of As removed from GW A column was $10041 \mu \mathrm{g}$ (15\% of total As mass) and that of GW B was $17326 \mu \mathrm{g}(25 \%)$. 


\subsubsection{DW column}

Fig. 4 shows changes in $\mathrm{pH}$ and Eh values of effluents from DW soil columns with time. The $\mathrm{pH}$ of effluent showed a narrow spread between 6.9 and 8.0 and was higher in first 80 days in DW A and 60 days in DW B column. Eh of effluents decreased to $-100 \mathrm{mV}$ but suddenly increased at 80 days for DW A and 60 days for DW B column. In these periods the columns were clogged and narrow channel might be created in the soil which seemed to be the cause of increase in Eh value. The column was partially washed and the channels were closed by shaking and settling the soil layers. After 120 days Eh of both columns decreased again and became less than $-100 \mathrm{mV}$.
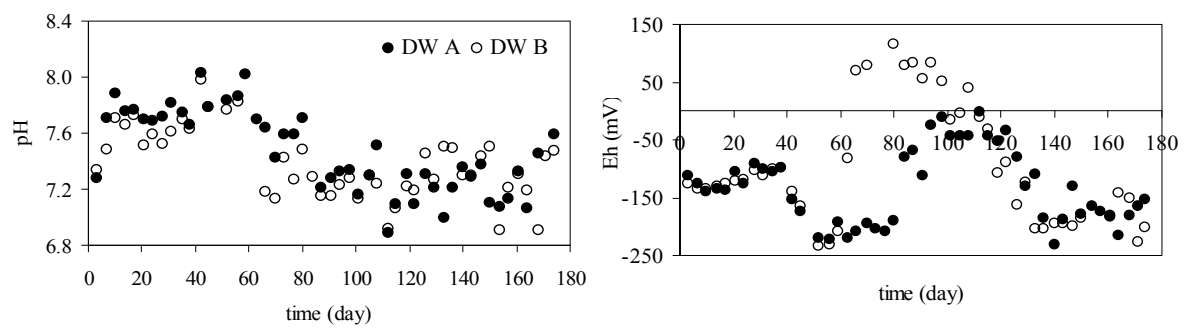

Fig. 4. Changes of $\mathrm{pH}$ and Eh values of effluents from DW soil columns with time.
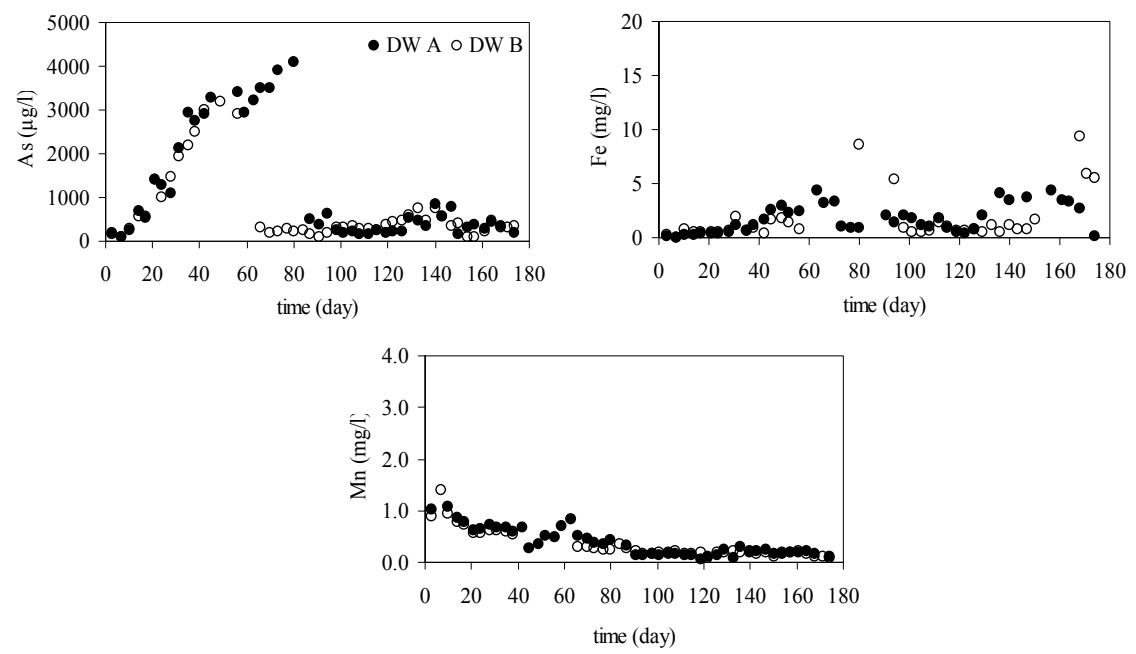

Fig. 5. Changes of effluent As, Fe and Mn of DW columns with time.

Fig. 5 shows the changes of As, Fe and Mn concentrations of the DW column effluents with time. Effluent As concentration increased until 80 days in DW A and 60 days in DW B. The highest concentration was found to be 4100 and $3200 \mu \mathrm{g} / \mathrm{L}$ in DW A and DW B, respectively. As concentration of effluent was lower when Eh was higher (oxidation condition) created due to clogging of the columns but after Eh decreased to less than -100 $\mathrm{mV}$ As increased slightly in 120 days and decreased again in 160 days. Fe concentration of effluent showed slight increase from 60 days to 80 days when Eh was less than $-200 \mathrm{mV}$. 
Between 140 to 160 days effluent Fe of DW columns increased again when Eh was less than $-200 \mathrm{mV}$. Fe release of DW B column was often high but it was caused due to release of particulate Fe by channeling (data excluded). Mn concentration in the effluent was high initially $(1.0 \mathrm{mg} / \mathrm{L})$ and decreased gradually with time.

Column DW A showed highest desorption with the mass of As removed was $27094 \mu \mathrm{g}$ (41\% of the total mass) and that of DW B was $19065 \mu \mathrm{g}(28 \%)$.

\subsection{Effect of Ca and $\mathrm{Mg}$ on As release}

Column leaching experiment results showed in section 3.2.1 and 3.2.2 indicated that total amount of effluent As was higher in DW columns than that of GW columns. This difference of released As amount could be explained by the difference of chemical composition such as $\mathrm{Ca}, \mathrm{Mg}, \mathrm{P}$ and $\mathrm{Mn}$ in the influent water. In order to observe the effect of chemical composition for As release the batch tests were carried out. Fig. 6 showed the results of leaching concentrations of As, Fe and Mn obtained in batch tests. In B-1 As and Fe released concentrations were $74.8 \mu \mathrm{g} / \mathrm{L}$ and $9.22 \mathrm{mg} / \mathrm{L}$, respectively. While in B-3 As and Fe concentrations were $85.0 \mu \mathrm{g} / \mathrm{L}$ and $13.5 \mathrm{mg} / \mathrm{L}$, respectively. In all cases $\mathrm{pH}$ was almost neutral and Eh was always positive.

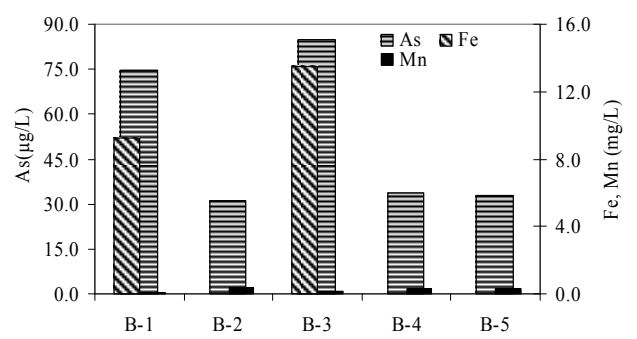

Fig. 6. Leaching of As, Fe and Mn in different conditions.

On the other hand, comparatively less amount of As $(31.1 \mu \mathrm{g} / \mathrm{L}, 33.8 \mu \mathrm{g} / \mathrm{L}$ and 32.7 $\mu \mathrm{g} / \mathrm{L}$ ) was released in B-2, B-4 and B-5, respectively. In these cases Fe (less than 0.05 $\mathrm{mg} / \mathrm{L}$ ) and $\mathrm{Mn}$ (less than $0.50 \mathrm{mg} / \mathrm{L}$ ) released amount was very small. B-1 and B-3 did not contain $\mathrm{Ca}$ and $\mathrm{Mg}$, while B-2, B-4 and B-5 contained both $\mathrm{Ca}$ and $\mathrm{Mg}$ or either $\mathrm{Ca}$ or $\mathrm{Mg}$. Therefore, these results clearly indicated that $\mathrm{Ca}$ and $\mathrm{Mg}$ would decrease the release of $\mathrm{As}$ and Fe from soil.

\section{Discussions}

\subsection{Release of As, Fe and Mn}

Results of the continuous column leaching experiment indicated that As was released when Eh was less than $-100 \mathrm{mV}$ i.e. under moderate to high reducing conditions. Increase in soluble As upon reduction had been attributed to the change of As (V) to more soluble As 
(III) [25-27]. $\mathrm{pH}$ varied narrow (6.8 8.2) in the studied columns and effect of $\mathrm{pH}$ on As release was not significant. However, As solubility increases under high acidic and high alkaline conditions and lowest in the neutral condition [23,28]. As solubility due to changes in Eh and $\mathrm{pH}$ can be explained by Eh-pH diagram for As- $\mathrm{H}_{2} \mathrm{O}$ system (Fig. 7). Effluent As, $\mathrm{Fe}$ and $\mathrm{Mn}$ of GW columns were also indicated in the figure which was divided into first stage ( $0 \sim 40$ days), second stage (40 80 days) and third stage (80 174 days). Three stages were defined according to the change of $\mathrm{pH}$, Eh and As concentrations of the effluent. In the first stage $\mathrm{pH}$ varied from 7.2 to 8.0 and Eh varied from -95 to $-140 \mathrm{mV}$. At this stage both As and Mn solubility was high due to reduction of As (V) to soluble As (III) and $\mathrm{MnOOH}$ to $\mathrm{Mn}^{2+}$ but Fe solubility was small due to lower amount of Fe (III) reduction to Fe (II). The reduction of $\mathrm{Mn}$ oxide is thermodynamically more favorable than the reduction of $\mathrm{Fe}$ hydroxide [13]. Second stage for GW A pH varied from 7.3 to 8.2 and Eh varied from -160 to $-250 \mathrm{mV}$. For GW B pH varied from 7.2 to 7.7 and Eh varied from -200 to $-250 \mathrm{mV}$. In this highly reducing condition As, $\mathrm{Mn}$ and Fe solubility were high in the effluent of the columns which supported the conditions of Eh-pH diagram (Fig.7). Third stage for GW A $\mathrm{pH}$ varied from 6.8 to 7.5 and Eh varied from -85 to $-190 \mathrm{mV}$. For $\mathrm{GW} \mathrm{B} \mathrm{pH}$ varied from 6.9 to 7.5 and Eh ranged between -145 to $-230 \mathrm{mV}$. This stage of Eh-pH diagram indicated high solubility of As, Mn and Fe. But effluent of column showed that As, Mn and Fe concentration dropped and remained almost constant. As might be decreased due to the reduction of easily soluble As in the columns during that time period. Decrease of $\mathrm{Mn}$ seemed to be caused by precipitation as Mn arsenate [29]. Second and third stage showed higher Fe concentration in the effluent of GW B compared to GW A. Eh values of GW B was enough to reduce Fe (III) to Fe (II) but in case of GW A column it did not.

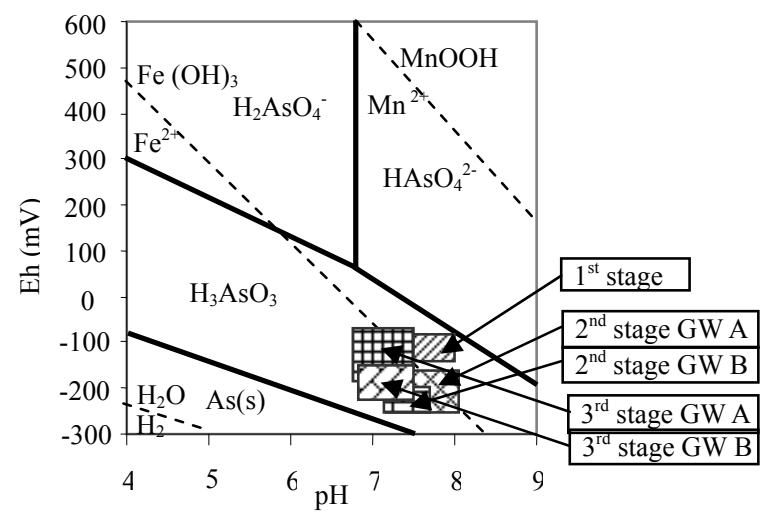

Fig. 7. Eh-pH diagram for As- $\mathrm{H}_{2} \mathrm{O}$ system and conditions of $\mathrm{GW}$ column effluents.

DW columns showed similar nature of As, Mn and Fe solubility with exception of some high value of soluble Fe was found in the effluents seemed to be due to the accident and clogging occurring in the columns.

In the practical field conditions As in the sampled soil seemed to come from the irrigation groundwater and adsorbed on the surface of soil. In the dry season adsorbed As 
was stable but during wet season it could be released due to change of redox potentials due to filling the pore of soil by the increase of groundwater level or rain water infiltration. The fact that higher As release from DW column compared to GW column suggested that much amount of As could be released during wet season due to rainfall as DW simulated rainwater condition.

\subsection{Effect of Ca and $\mathrm{Mg}$ on As release}

As mentioned earlier that released amount of As was higher in DW columns than GW columns. The probable cause for the difference of released As amount was attributed due to the difference of chemical composition such as $\mathrm{Ca}$ and $\mathrm{Mg}$ of the influent water. Results indicated that $\mathrm{Ca}$ and $\mathrm{Mg}$ in DW columns were released but were accumulated from the synthetic groundwater in the GW columns (data not shown). Batch experiment results clarified that $\mathrm{Ca}$ and $\mathrm{Mg}$ would decrease As release from soil. Among the five conditions B-2 contained both $\mathrm{Ca}$ and $\mathrm{Mg}, \mathrm{B}-4$ contained Mg and B-5 contained $\mathrm{Ca}$. While B-1 and B-3 did not contain $\mathrm{Ca}$ and $\mathrm{Mg}$ and released high amount of As and Fe. B-3 showed the slightly higher As release. The difference between B-1 and B-3 was due to the presence $\mathrm{P}$ $(1.0 \mathrm{mg} / \mathrm{L})$ in the $\mathrm{GW}$ solution which enhanced the release of As from soil by competing for adsorption sites [30-32]. Batch test suggested that $\mathrm{Ca}$ and $\mathrm{Mg}$ would also decrease the release of Fe in B-2, B-4 and B-5.

Fig. 8 showed the comparison between the percentage of total released As from the columns and the acid-alkali sequential extraction. Percentage of the released As in GW columns were almost same to the percentage of easily soluble fraction of acid-alkali extraction. It suggested that using GW only the easily soluble fraction of As could be released. In case of DW columns percentage of released As was more than about 5\% compared to GW columns. These results suggested that some part of Fe bound As was also released from the DW columns indicating partial dissolution of Fe oxyhydroxide which led to an increase in As concentration [33]. Ca and $\mathrm{Mg}$ of GW seemed to affect and decrease the amount of released As bound with Fe.

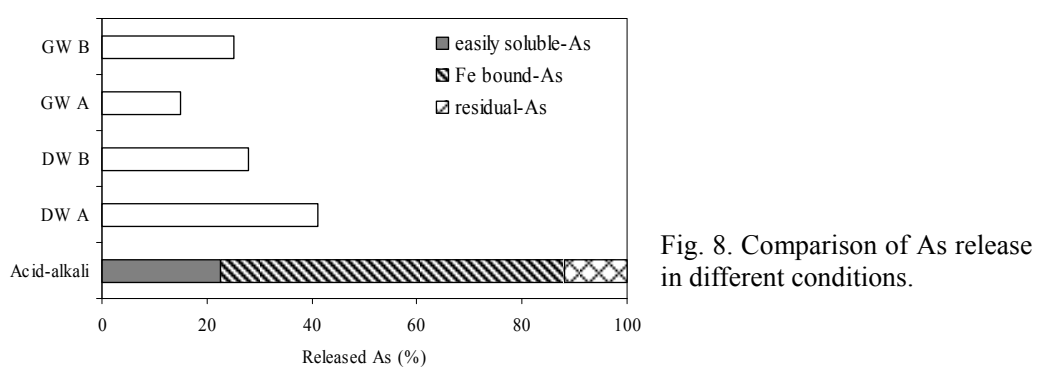

Some dissolved As can be precipitated as a rich $\mathrm{Ca}$ and $\mathrm{Mg}$ arsenate solid in $\mathrm{As}$ contaminated soils because of the high content of $\mathrm{Ca}$ and $\mathrm{Mg}$ in the ground water [34-36]. Smith et al. (2002) [37] showed that Ca increases As sorption by soils through changes in the surface charge characteristics of the soils. $\mathrm{Mg}$ salts are used to promote As fixation in soils and $\mathrm{Mg}$ arsenate solubility is similar to $\mathrm{Ca}$ arsenate [35]. 
The role of $\mathrm{Ca}$ and $\mathrm{Mg}$ in decreasing the As solubility from soil suggested that addition of excess $\mathrm{Ca}$ and $\mathrm{Mg}$ in paddy field would decrease the movement of As in soil. The source of easily available $\mathrm{Ca}$ and $\mathrm{Mg}$ in the rural areas of Bangladesh like shellfish, coral and eggshell etc. would be useful for the remediation of As contamination in soil. Further research would be necessary to clarify the mechanism of As remediation by the addition of $\mathrm{Ca}$ and $\mathrm{Mg}$.

\section{Conclusions}

Column leaching test with DW and GW using actual contaminated soil indicates a strong dependence of redox potential on As solubility. $\mathrm{pH}$ value is also seen to vary within a narrow range in the studied columns and the effect of $\mathrm{pH}$ on As release is not significant. In highly reducing conditions the solubility of $\mathrm{As}, \mathrm{Mn}$ and $\mathrm{Fe}$ is found to increase. The important findings from this study are as follows:

a. DW accelerates the release of As from the soil adsorbed on the surface as well as bound with Fe, while GW could not release Fe bound As. This mechanism is proved by comparing the percentage of released As with the acid-alkali extracted fractions.

b. The presence of $\mathrm{Ca}$ and $\mathrm{Mg}$ in the GW causes the difference between the DW and $\mathrm{GW}$ column effluent As. Batch test results also show that $\mathrm{Ca}$ and $\mathrm{Mg}$ reduce the release of As and Fe from soil.

c. The rain water and groundwater have potential effects on As mobilization from soil to groundwater and vice versa. A larger amount of As is released during wet season due to rainfall.

d. Effect of $\mathrm{Ca}$ and $\mathrm{Mg}$ on As release from soil observed in this study would assist in further research to clarify the mechanism of As remediation from soil.

\section{Acknowledgment}

The authors would like to express their thanks to KUET and ADAMS for their kind cooperation in sample collection and using laboratory for this study. A part of this study was funded by KAKENHI (18560534).

\section{Reference}

1. D. G. Kinniburgh, P. L. Smedley, J. M. Trafford, C. J.Milne, S. M. I. Hug, K. M. Ahmed, and S. Burden, British Geological Survey, UK (Chapter 6), 77 (2001).

2. M. Berg, H. C. Tran, T. C. Nguyen, R. Schertenleib, and W. Giger, Environ Sci. Technol. 35, 2621 (2001). doi:10.1021/es010027y

3. D. Chakraborti, M. M. Rahman, K. Paul, U. K. Chowdhury, M. K. Sengupta, D. Lodh, C. R. Chanda, K. C. Saha, and S. C. Mukherjee, Talanta 58, 3 (2002). doi:10.1016/S0039-9140(02)00270-9

4. B. K. Mandal and K. T. Suzuki, Talanta 58, 201 (2002). doi:10.1016/S0039-9140(02)00268-0

5. J. C. Ng, J. Wang, and A. Shraim, Chemosphere 52, 1353 (2003). doi:10.1016/S0045-6535(03)00470-3

6. D. A. Polya, A. G. Gault, N. Diebe, P. Feldman, J. W. Rosenboom, E. Gilligan, D. Fredericks, A. H. Milton, M. Sampson, H. A. L. Rowland, P. R. Lythgoe, J. C. Jones, C. Middleton, and D. A. Cooke, Mineral Mag. 69, 807 (2005). doi:10.1180/0026461056950290

7. M. J. Abedin, J. Cotter-Howells, and A. A. Mehrag, Plant Soil 240, 311 (2002). doi:10.1023/A:1015792723288 
8. P. L. Smedley and D. G. Kinniburgh, App. Geochem. 17, 517 (2002). doi:10.1016/S0883-2927(02)00018-5

9. A. S. Pastor and F. Burlo, Geoderma. 137, 504 (2007). doi:10.1016/j.geoderma.2006.10.012

10. R. P. Gambrell and R. A. Khalid, Environ. Sci. Technol. 14, 431 (1980). doi:10.1021/es60164a012

11. W. Stumm and B. Sulzberger, Geochim. Cosmochim. Acta 56, 3233 (1992). doi:10.1016/0016-7037(92)90301-X

12. K. M. Ahmed, P. Bhattacharya, M. A. Hasan, S. H. Akhter, S. M. M. Alam, M. A. H. Bhuyian, M. B. Imam, A. A. Khan, and O. Sracek, Appl. Geochem. 19, 181 (2004). doi:10.1016/j.apgeochem.2003.09.006

13. J. M. McArthur, D. M. Banerjee, K. A. Hudson-Edwards, R. Mishra, R. Purohit, P. Ravenscroft, A. Cronin, R. J. Howarth, A. Chatterjee, T. Talukder, D. Lowry, S. Houghton, and D. K. Chadha, Applied Geochemistry 19 (8), 1255 (2004). doi:10.1016/j.apgeochem.2004.02.001

14. A. Mukherjee and P. Bhattacharya, Environ Rev. 9, 189 (2001). doi:10.1139/er-9-3-189

15. P. Ravenscroft, J. M. McArthur and B. A. Hoque, In: Arsenic exposure and health effects IV, Eds W.R. Chappel et al. (Elsevier Science Ltd. Oxford, 2001) pp 53-78.

16. Y. Zheng, M. Stute, A. van Geen, I. Gavrieli, R. Dhar, H. J. Simpson, P. Schlosser, and K. M. Ahmed, Appl. Geochem. 19, 201 (2004). doi:10.1016/j.apgeochem.2003.09.007

17. J. Gulens, D. R. Champ, and R. E. Jackson, American Chemical Society Symposium Series 93, 81 (1979).

18. P. D. Kuhlmeier, Journal of soil Contamination 6(1), 21 (1997a).

19. D. Shaw, Engineering Geology 85, 158 (2006). doi:10.1016/j.enggeo.2005.09.035

20. V. Chatain and F. Sanchez, Journal of Hazadous Materials B 122, 119 (2005). doi:10.1016/j.jhazmat.2005.03.026

21. British Geological Survey (BGS), Main report and supplemental vol. 1-3, (2000). http://www.bgs.ac.uk/arsenic

22. N. P. Nickolaidis, L. A. Hellerich, and J. A. Lackovic, Environ Sci. Technol. 33 (17), 2910 (1999). doi:10.1021/es990230h

23. S. Azam, M. Shafiquzzaman, I. Mishima, and J. Nakajima, Journal of Scientific Research 1(1), 92 (2009). www.banglajol.info/index.php/JSR

24. A. A. Mehrag and M.M. Rahman, Environ. Sci. Technol. 37, 229 (2003). doi: $10.1021 /$ es 0259842

25. L. E. Duel and A. R. Swoboda, Soil Sci. Soc. Am. J. 36, 276 (1972).

26. P. H. Masscheleyn, R. D. Dlaune, and W. H. Patrick Jr., Environ. Sci. Technol. 25, 1414 (1991). doi:10.1021/es00020a008

27. M. Sadiq, Water Air Soil Pollut. 93, 117 (1997).

28. Souhail R Al-abed, G. Jegsdeesan, J. Purandare and D. Allen, Chemosphere 66, 775 (2007).

29. G. Sposito, and S. V. Mattigold, GEOCHEM, University of California, Riverside, CA (1979).

30. E. A. Woolson, J. H. Axley and P. C. Kearney, Soil Sci. Soc. Am. Proc. 35, 938 (1971a).

31. B. Manning and S. Goldberg, Soil Sci, Soc. Am. J. 60, 121 (1996).

32. F. Liu, A. De Cristofaro, and A. Violante, Soil Science 166 (3), 197 (2001). doi:10.1097/00010694-200103000-00005

33. R. T. Nickson, J. M. McArthur, P. Ravenscroft, W. G. Burgess, and K. M. Ahmed, Appl. Geochem. 15, 403 (2000). doi:10.1016/S0883-2927(99)00086-4

34. T. Nishimura, C. T. Ito, K. Tozawa and R. G. Robins. Impurity, Control and disposal, Proceedings 15th Annual Hydrometallurgical meeting, Vancouver, Canada (1985) pp. 2.1-2.19

35. M. Clara and F. Magalhaes, Pure Appl. Chem. 74 (10), 1843 (2002). doi:10.1351/pac200274101843

36. D. E. Voigt, S. L. Brantley, and R. J. C. Hennet, Appl. Geochem. 11, 633 (1996). doi:10.1016/S0883-2927(96)00009-1

37. E. Smith, R. Naidu, and A. M. Alston, J. Environ. Qual. 31, 557 (2002). 